\title{
Laughing and Learning Together: Intersections of Socioemotional Activity with Science Talk
}

\author{
Sara Hagenah* \\ Department of Curriculum, Instruction, and Foundational Studies, College of Education, Boise State University, Boise, Idaho, USA
}

*Corresponding Author: sarahagenah@boisestate.edu

\section{ABSTRACT}

Culturally sustaining and science education theorists advocate that children need to have opportunities to use personal experiences and background knowledge in dialog with peers as they make sense of phenomena in the natural world. Practically, this is a challenge to orchestrate - both in classrooms and in out-of-school learning spaces - as teachers and learners navigate the personal, interpersonal, and structural components of talk. What is not well understood, are the multitudes of social interactions that support rigorous and responsive talk. In this paper, I examine how a group of 19 middle school young women fell into naturally occurring forms of friendship talk as they learned science concepts and learned to take a stand against a toxic lake next door to their school. This multiple case study examined moment-to-moment discourse and interactions between students including facial expressions and body movements to explore the connection between everyday human social activity and productive science. Analysis revealed patterns of strangely familiar forms of friendship and how they were instrumental in constructing a nature walk and an animated film about saving the local lake for community members. This research indicates the need for structured opportunities in science classrooms to share ideas that are also linked to student social and emotional connections.

KEY WORDS: culturally sustaining pedagogy; equity; informal science education; laughter; sense of belonging

\section{INTRODUCTION}

$\circlearrowleft$ cience lessons are not one sided in their emotional tenor, merely serious, but take on aspects of life in general. It is precisely when science lessons take on the same characteristics as life more broadly, when they are serious and humorous, when they embody the generative principles of life, that they reflect a greater truth than they are one-sidedly serious (Roth et al., 2011, pp. 455-456).

Culturally sustaining and science education theorists advocate that children need to have opportunities to use personal experiences and background knowledge in dialog with peers as they make sense of phenomena in the natural world (Banks et al., 2007; Paris, 2012; Thompson et al., 2016). Practically, this is a challenge to orchestrate - both in classrooms and in out-of-school learning spaces - as teachers and learners navigate the personal, interpersonal, and structural components of talk. Science is a serious discipline that requires serious thinkers and makers of new knowledge, but science is not void of emotion and everyday social interaction (Jaber and Hammer, 2015, 2016; Roth et al., 2011). Recent studies provide evidence of the positive association between attending to social and emotional aspects of science learning spaces (Davis and Bellocchi, 2018; Jaber and Hammer, 2015, 2016; King et al., 2017). What is not well understood, are the multitudes of social interactions that support rigorous, responsive, and fun talk. What is the role of humor? Of pride? Of becoming friends? How are everyday social interactions that make science discourse like everyday discourse used as resources to create intimate bonds that students can then leverage when working together to make progression on science ideas?

In this paper, I examine how a group of 19 middle school young women (young women aged 11-14 years old) in an afterschool science club built on shared histories of being female, ethnic minorities, and classmates in school. Important to their learning space was the way they fell into naturally occurring forms of friendship talk as they learned science concepts and learned to take a stand for a toxic lake next door to their school. Using a multiple case study approach method, I examined physical activity and student talk in the afterschool club to explore the connection between everyday human social activity and productive science activity. I describe patterns of strangely familiar forms of friendship and how they were instrumental in constructing a nature walk and an animated film about saving the local lake for community members. The research questions for this study were as follows:

1. How do socioemotional (SE) interactions intersect with science talk?

2. How do SE interactions act as resources across science conversations?

\section{Theoretical Framework}

This study is framed by ideas found within culturally sustaining pedagogy and sense of belonging theories where language, ideas, and practices shared by students in learning spaces are valued (Faircloth, 2009; Moje et al., 2004; Osterman, 2000; 
Paris, 2012). Student language and practices are not void of emotion or social interactions and learning spaces should aim to capitalize on such interactions as laughter, friendship, comfort, and pride. Research shows that when sense making talk is supported in the classroom, teachers ask students to reason with what they know using their lived experiences from in and out of school (Barton and Tan, 2010; Sohmer et al., 2009; Warren et al., 2001; Windschitl et al., 2012).

\section{Valuing Student Ideas and Ways of Being}

Framed by ideas found in culturally sustaining pedagogy, this study focuses on how students form relationships as they engage in meaningful science activity (Paris and Winn, 2014). Planning both the pedagogical and social components of the afterschool club considered the "shifting and changing practices of students and their communities" (Paris, 2012, p. 94) and "building relationships of care and dignity and dialogic consciousness" (Paris and Winn, 2014, p. xvi). Student language, ideas, and their interactions between and with each other shaped how science was learned and used in their community. This pedagogy valued and maintained students' ways of being and ideas, recognizing that student language and practices were not void of emotion or social interactions. This study frames the language, ideas, and practices shared by students in the afterschool club as valued contributions, with the understanding that all ideas need exposure to make progress on science explanations of naturally occurring phenomena. This study explores what happens when teachers capitalize on interactions as laughter, friendship, comfort, and pride in connection with productive science talk.

Productive Science Talk in Moment-to-moment Interactions Academically productive talk includes both rigorous and responsive talk and tasks where students use lived experiences to make sense of given phenomena (Sohmer et al., 2009; Thompson et al., 2016). Science sense making talk can be facilitated and fostered in a variety of ways depending on how the students' ideas are attended to as sense making resources. Student revision of and construction of scientific causal explanations are fostered by sense making talk that takes place in a science learning space. Throughout a unit, students add to, revise, modify, and question working models and a causal explanation of the puzzling phenomenon while working and talking together in small and whole groups.

Research shows that when sense making talk is supported in the classroom, teachers ask students to reason with what they know using experiences that they have had in and out of school (Barton and Tan, 2010; Warren et al., 2001; Windschitl et al., 2012). This type of support allows students to see science as part of their lived experiences and helps reanimate the science in the lived experience. What is not yet understood are the roles of social interactions that naturally occur as these life connected productive conversations occur and how social interactions support these productive science conversations. This study aims to extend this idea and fill an understanding of how teachers and students use social interactions as a sense making resource in classroom talk.

\section{Belonging to an Action-oriented Science Community}

Belonging to a community means that members communicate and interact with each in a relational way, have social and emotional connections, and at times a shared goal (Faircloth, 2009; Hamm and Faircloth, 2005; Osterman, 2000). "A community exists when its members experience a sense of belonging or personal relatedness" (Osterman, 2000, p. 324). In this study, I investigate student interactions and talk to understand how the sense of belonging and forming friends intersects with academic science activity. Specifically, I investigate where these intersections occur as the young women work together toward the common goal of using science knowledge to act in their communities.

\section{METHODS}

Using a multiple case study approach, this study examined cases of intersecting social interactions with productive science talk over one school year in the afterschool club. Discourse, both talk and non-verbal actions in video of meetings, student interviews, and student artifacts were examined to see how the young women participated in the club (Barton et al., 2008; Gee, 2011; Yin, 2009). A case study approach in this study is appropriate because it provided an opportunity for an in-depth description of the different ways in which the young women participated and identified with and in science (Yin, 2009). This method of qualitative research allowed for in-depth analysis of the discourse that occurred between the club participants as they interacted with each other in, across, and on the margins of activity. In this section, I describe the research context, participants, data sources, and data analysis.

\section{Research Context}

\section{Afterschool science club}

The science club was an afterschool space located in a school for 11-14-year-old students, where 19 middle school young women came to do science and produce a documentary film about how they decided to use their science knowledge about a local issue to take action in their community. It was not a predefined space, as it was open to whom the young women were and what science they cared about taking a stand for. In this club, the young women were the knowledge experts and negotiators of how they would use their science knowledge to act in their community on an issue that they cared deeply about.

The young women in the club decided to investigate why Lake Evergreen (pseudonym), a lake they could see outside of their science classroom window and located in a park many of them walked through when coming to and from school, was polluted and why it was taking so long to clean it up. They cared to speak up for those in and around the lake that could not speak up for themselves - the environment, wildlife, and future generations. Sixty years ago, the lake was a place 
where the community gathered to picnic, swim, and fish. At present, the lake contained little to no life and was monitored for toxic cyanobacteria blooms in the warm summer months. The lake was a place of urban legend with many stories flying around including that there was a dead horse on the bottom of the lake, a guessing game about how many cars were on the bottom of the lake - wonderment was framed by the desire for it be a place of recreation again. The surrounding park was also known for its drug activity and crime, with many students expressing the feeling of being unsafe as they walk through and by this park every day. The science club meetings were filled with activity around constructing a deep understanding of the science behind Lake Evergreen's pollution and ways they could help engage the community in taking steps toward a better future for the lake and all those that use it.

\section{Participants}

\section{Middle school students}

Nineteen students from ages 11-14 participated in the club and were recruited through a community recruitment process that included advertising during lunch and at parent curriculum night. One of the lead teachers recruited some students from her science class that she taught. All the young women in the club attended a high poverty school, Mountain Middle School (pseudonym), with a free and reduced lunch rate of $86 \%$. Mountain Middle School hosted over 583 students that spoke over 20 different languages, with $21 \%$ of the students designated as transitional bilingual. All students voluntarily agreed to participate, and the students and their parents gave informed consent to be in this study.

\section{Lead teachers}

Recruitment of the lead teachers included letting teachers that I have worked with in the past know about the program and asking for teachers potentially interested in leading the formal out of school science program. The two teachers who responded, Collette and Emerson (all names are pseudonyms), were teachers that I had worked with for 3 years on three other research studies around ambitious and equitable science teaching (Thompson et al., 2016). Emerson, the middle school science lead teacher, was the science teacher of many of the middle school students and hosted the program in her classroom every week. Collette, the high school science lead teacher, taught at one of the feeder high schools that many middle school students from the club could apply to go to upon graduation from middle school. The school that Collette taught at focused on the health sciences and was built around the concept of small schools, meaning that she knew each of her students very well. Collette taught many of the middle school students' older siblings and was able to engage in conversation with many of the students about their siblings. Both lead teachers gave informed consent and volunteered to participate in this study.

\section{Researcher's role}

I took on the role of research participant in this study along with one other University researcher. We coplanned, coled, participated, and codebriefed all science club meetings with Collette, Emerson, and community members.

\section{Data Sources, Collection, and Analysis}

Data collection included over $100 \mathrm{~h}$ of afterschool meeting video, $40 \mathrm{~h}$ of individual and group interviews, and student artifacts collected over 1 year in an afterschool science club for underserved middle school young women. Using ethnographic and discourse analysis techniques, data were coded according to what patterns of science sense making talk emerged alongside everyday social activities such as fun and laughter in science spaces, comfort in sharing ideas in an allfemale space, sense of belonging with each other, and feeling proud of yourself (Barton et al., 2008; Gee, 2011; Yin, 2009).

\section{FINDINGS}

Findings reveal that SE interactions intersected with science talk and were used as resources in four significant ways. I answer the two research questions, (1) how do SE interactions intersect with science talk and (2) how do SE interactions act as resources across science conversations as four case studies of intersecting SE and science activity: Fun and laughter in science spaces, comfort in sharing ideas in an all-female space, sense of belonging with each other, and feeling proud of yourself. Each case study presents a picture of how SE pathways intersected with science activity as the young women shared ideas across small and whole group interactions as they worked together on a collective goal to take action in their community.

\section{Fun and laughter while doing serious science work}

Laughter and fun infused all aspects of science and social activity in the club. Laughter was shared between students and with teachers. Laughter and fun formed a bond that became about working together to understand the science behind the polluted lake as they inserted jokes, performed dances, sang the song of the day, and viewed investigation mistakes as hilarious mishaps. An example of this took place in the small expert explanation group that focused on why there was so much excess nutrient phosphate in Lake Evergreen. Many different factors cause too much phosphate to enter Lake Evergreen including use of fertilizer, dog waste, sewage waste entering lake, and excess waterfowl feces. The fact that excess waterfowl feces were a significant contributor to increased phosphate levels in the lake became a focal point of laughter for this group of middle school young women. In the following excerpt, one teacher is working with five students in constructing a scientific model of what the external sources of phosphate are. There is a piece of poster paper in the middle of the table that the young women are drawing their scientific model on as they discuss a reading from the county about how phosphorus enters Lake Evergreen.

( $\mathrm{T}=$ teacher, $\mathrm{S}=$ student)

T: It (phosphorus) helps the plants grow. How does it help plants grow? What do we know about it?

S1: Let's see, it (referring to reading) says that phosphorus is in...poop. 
T: Yeah (laughs), basically.

S2: Yep, it's in the poop.

(Whole group laughter)

S1: It says it is in poop and in wastewater.

S3: Is there poop in the lake?

(Whole group laughs)

T: Oh yeah. That's why we did a bird survey last year because they (the county) wanted to know where the birds hung out and pooped.

(Laughter)

S2: (Laughing) You're kidding right?

$\mathrm{T}$ : No, the county asked us to survey where the birds were because where they are is where they poop. They don't walk to a bathroom like we do, they just poop where they are. (Whole group laughter).

This part of the conversation was interwoven with other informal topics, with the young women talking about the science behind how phosphorus entered the lake and saying stating this in their different languages while trying on various accents as they spoke - which prompted further laughter. Following this excerpt, Lan (student two) volunteered to draw the geese and poop on their scientific model, showing how the phosphate from the poop gets into the lake, with student three drawing in wastewater that carried the feces into the lake. This laughter-filled conversation about bird poop and its significance in the overall scientific story started here and seeped into future meetings when the phosphate source of bird feces would come up in conversation. Lan, who originally volunteered to draw the bird poop on the scientific model, became known as the "poop advocate" in both small and whole group settings. Whenever the topic of pet or bird waste arose, there was always an undertone of laughter in the whole group and Lan, especially made sure that the poop problem in relation to the pollution was never forgotten.

The use of laughter and fun while doing serious science work was not only shared between students but also between students and teachers. Teachers felt that there could be more "fun" in the afterschool space and the young women noticed the more relaxed, humorous nature of teachers in the club. For example, the lead teacher Emerson, who was also the school science teacher of many of the young women in the club, stated, "I liked (the science club) so much because I sort of got to take on a different role with many of the young women and it was just like more relaxed and more fun. Which was nice." When working with the young women, Emerson would facilitate productive science conversations and interactions, but also insert her own humor into discussions with the young women. While working on a science investigation with her small expert group she shared a joke/riddle a fellow science teacher had shared with her:

T: Ms. Ohler shared a joke with me. She said if heat is molecules moving faster does blowing on your food really make it colder?

Ss: Ha ha...
T: Do you get it?

Ss: Yeah...Ha, ha!

$\mathrm{S}$ : Yeah, so if you are blowing on your food is making molecules move faster is it really cooling it?

Emerson was able to intermittingly make this casual conversation with the young women as they did serious science business. After the club was over, Nina described Emerson in the afterschool space in comparison to her school science classroom as being happier:

In (the club) she was more fun... she was more happy or it seemed like she was ... In school she was more strict. Because she knows in school you have to follow the rules and in (the club) she didn't. So, I think she was funner. (Nina, $8^{\text {th }}$ grade)

Laughter became an intricate part of the productive positive atmosphere that was integral for the young women to work together and act together (Roth et al., 2011). Allowing for fun and laughter is akin to taking up and using students' everyday experiences and language, but extends these practices to incorporate everyday interactions such as using humor in the classroom as a way to enhance learning experiences and seriously make learning more enjoyable. The balance between construction of serious science knowledge and/or taking action and having fun with each other strengthened the group as a working group, bonding them together through "inside jokes," and finding humor through science.

Pictures and videos taken throughout the club display laughter in small group work (Figure 1, pictures 1a-1d), when presenting information to the whole group, when informally socializing, and when working in expert pollution and solution groups. The mix of laughter, fun, and seriousness created "intimacy, complicity, and solidarity" (Roth et al., 2011, p. 454) between the young women that enabled them to interact in a way that resembled interactions in less restrictive everyday activities, allowing them to work productively together.

\section{Comfort in sharing ideas with other young women}

Like you're really shy and like you barely even do nothing (in science class) because there (are) guys around you, you know how young women are. And with young women you get along with them. Because they're young women and I'm a girl too. (Gloria, $8^{\text {th }}$ grade student)

Gloria's quote exemplifies shared reflections from many young women in the club on why they felt more comfortable sharing ideas in the all-female space versus in school science mixed gender class. They expressed this sense of comfort in being with all young women and feeling free to share any and all ideas:

Because we are all young women...we understand each other. (Paulina, $8^{\text {th }}$ grade)

We never laughed at each other for saying something. (Lan, $8^{\text {th }}$ grade)

We feel good with each other. It's like we are family, you know. (Hannah, $8^{\text {th }}$ grade) 


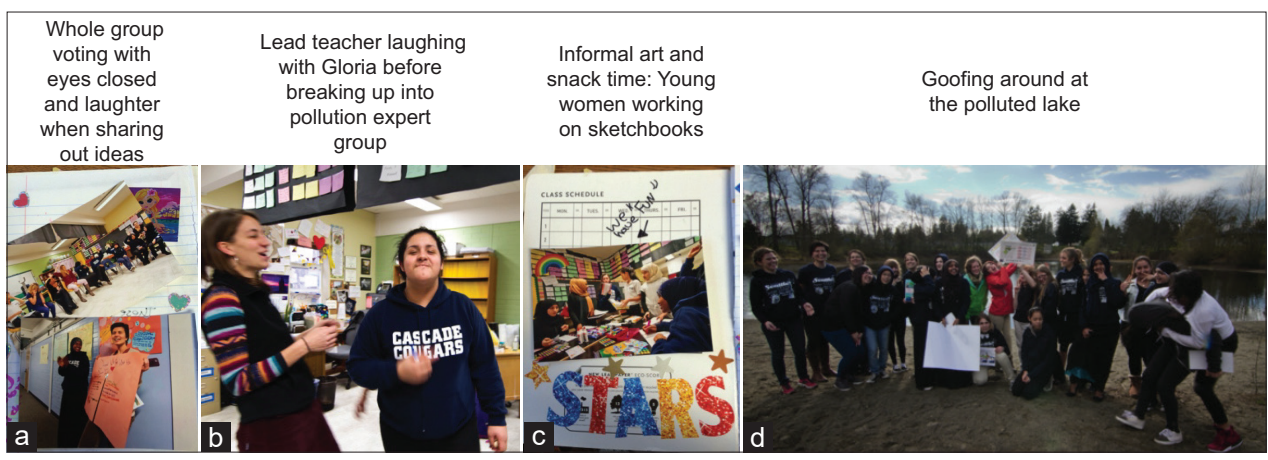

Figure 1: (a-d) Fun Times Throughout Science Club Activities

After I would say something, you like actually asked me about it, like you cared what I said. (Nina, $8^{\text {th }}$ grade) And I think people in (the club) are like more willing to participate and stuff because they know that in class you're going to feel like, "Oh, if I say this and people know I know the answer they're going to make fun of me," and just like dumb stuff that shouldn't happen but it happens all the time. Because, I don't know. It's just really dumb. But like with (the club) people can speak up and they know that, "Oh yeah, I can say this and people won't think I'm stupid or anything if it's wrong." Whereas like in class people are like, "Oh, that's wrong. Blah blah blah." And it just puts you down. (Donna, $8^{\text {th }}$ grade)

Being an all-female science space helped the young women shed their hesitation in sharing ideas with each other and created a safe, comfortable space where they knew their ideas were being heard and valued. In contrast with their school, science classroom where they felt constrained from being "laughed at" by boys in their classroom. One girl, Lana, expressed her experience of sharing one idea in science class, being laughed at by boys, and then not wanting to speak up again.

It was through careful consideration and planning for intentional ways of sharing that fostered how the young women came to feel comfortable sharing and listening to all ideas. First, sharing ideas were nurtured through intentionally planned activities that attended to the orchestration of small group sharing and constructing ideas in combination with whole group sharing of ideas (Figure 2). Ensuring that each girl had a voice in the club and ample opportunity to share science and life stories, small groups were given their own expert topics to investigate and build an evidence-based model on and were referred to as "small expert groups." Ample time was provided for each small group to share hypotheses, revise hypotheses, draw, and revise models based on new evidence, and also intentional and multiple opportunities for practice on what and how ideas would be shared with the entire group of young women (Figure 2, picture 2b). In other words, building and sharing ideas in small groups were extremely scaffolded and prepared the young women to feel comfortable sharing ideas with the larger group. In their small groups, they would also consider what questions they had for other groups who were studying other pieces of the overall community issue. As Paulina expressed in her post-club interview, "we like wanted to know what other people's ideas were about." They were prepared to show that they valued what the other young women had to share and were also eager to share their part of why Lake Evergreen was so polluted:

Well I was in one team, because there were three different - well we were a team as a whole but there were three different teams... as a team we would get to interact with each other, do fun experiments with other people, get to know them better... it's different than a class because in a class we would get a piece of appear and assignment and it would have to be done. But in (the club) we would be able to interact with people, talk, have fun, eat. And we would just have a lot more fun. (Paulina, $8^{\text {th }}$ grade)

Second, breaking into small expert groups not only scaffolded the process of sharing ideas but also aided the young women in being science experts of one part of the overall science explanation. There was no need for every girl to know the complete, complex story of why Lake Evergreen was so polluted and why it was so hard to clean it up, but rather for every girl to be part of the overall scientific explanation and be able to clearly explain their piece to the entire group and the community. It was in whole group discussions that the young women knew to rely upon each other to ask questions and collaborate to synthesize ideas. Synthesizing was possible because they had practiced and were primed to ask questions of other groups based on what they felt they did not know as a small group (Figure 2, pictures 2c and 2d). Expert groups were periodically mixed together with other groups to allow for whole group hypothesis sharing and progression of solution hypotheses. As Gloria stated, "If someone needed my help with something, then I could help them in the small expert group or in the whole group. Real easily."

The comfortable bond that formed through sharing ideas meant that the young women could share any idea and know they would be listened to, not be laughed at, and could trust that others needed their ideas so they could make progress on science ideas together. 


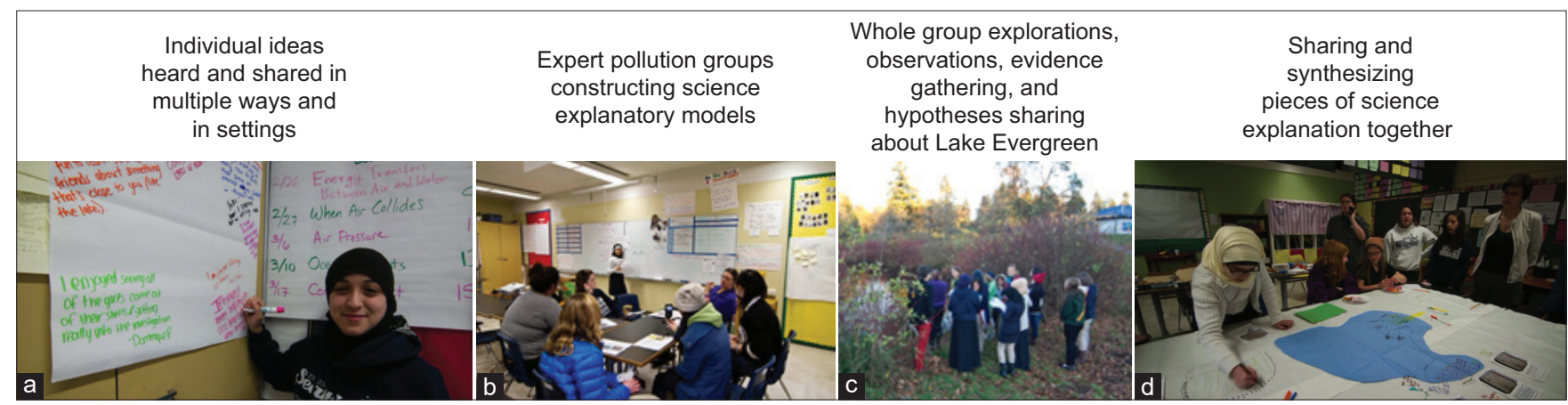

Figure 2: (a-d) All ideas heard, shared, and used together to make progression on science ideas

\section{Making new friends and belonging}

Like we're all - we're different but we get along with each other very well. We don't really care about our background, we just get along with each other. I don't think - well to me it doesn't matter whatever they are. If I get along with them okay, it's fine. (Selena, $8^{\text {th }}$ grade) It's like kind of amazing because it's people that you didn't know at first and then you're just coming all together and working with them and having this opportunity to get to know them better. (Sonya, $8^{\text {th }}$ grade)

The young women in the club were a small yet powerful group because they felt a sense of belonging to each other. This bond between them was novel as ethnic and cultural boundaries that kept them "apart" during the school day no longer existed and they were brought together through friendship and acceptance of the uniqueness of each person in the group. Planning for the young women to become friends was not possible, but planning a space where everyone felt like they belonged could be attended to in the planning process. To foster the sense of belonging meant that meeting time had to capitalize on informal social time together.

Before each meeting, the young women would meet in the cafeteria and then walk together to the meeting room (Figure 3, picture 3a). When they entered the meeting room, they were always full of laughter and lots of stories to tell. To capture this social time and transition to working on science ideas, part of the meetings was planned for art, snacks, and free talk so the young women could get to know each other and each other's interests. Informal socializing occurred and hoots of laughter, horseplay, and sharing of personal items such as art sketchbooks, music, and stories from in and out of school were shared with each other and with teachers took place in this unstructured time. It was in this period that the young women mixed up with each other and rather than any cliques forming, the groups formed a deep bond with and across each other:

Okay, so you know how like every school is divided into the popular clique and the nerdy clique? And well I noticed some of the popular young women who I was previously afraid of in (the club) and I was like, "I didn't know they would come to this. This is kind of scary," because they intimidate me because they can do a lot with their popular status. And so, but I've gotten to be more friends with them. Like I don't want to say names but.... (Hannah, $8^{\text {th }}$ grade)

Friendships were formed while doing science, sharing ideas, and supporting each other for who they were (Figure 3, pictures $3 \mathrm{~b}$ and $3 \mathrm{c}$ ). Forming new friends were about learning about each other and admiring differences that were present in the science space. Over half of our young women were Muslim and many of our Latina young women were able to ask questions around why they wore a scarf over their hair. Muslim young women were able to listen and ask about how to say certain words in Spanish. As exemplified by Hannah's reflection on why the club was fun, she reflected on how all young women were able to talk and ask each other questions about their lives:

I think (the club) was cool because there were frequently conversations about Arabic. Or about Somali. Or about Spanish. And like even Lily was able to participate in those conversations, you know? It would be like ask questions about - like, "When do you wear the hijab, why do you wear it?"

The sharing of whom the young women was as individuals with each other and the friendships that resulted became a natural part of the club and was easily visible in all interactions. This bond of belonging to and with each other was leveraged as they worked together as a group to make changes in their community. In the next section, I describe how pride was a feeling that many of the young women cherished for themselves and as a collective group (Figure 3, picture 3d).

\section{Proud to use science to take action in community}

All young women in their post-club interview expressed feeling proud of learning rigorous science, using their knowledge to act in the community, and most of all being able to communicate these ideas to a variety of audiences. These young women expressed feeling proud because they could have new conversations with their moms, dads, stepdads, sisters, and brothers about what they were doing in the club. Many of these conversations would take place on the way home from the club, while preparing dinner, while washing dishes at home, or over the weekend while visiting family. For example, Gloria $\left(8^{\text {th }}\right.$ grade) shared how after each meeting her mom would ask 


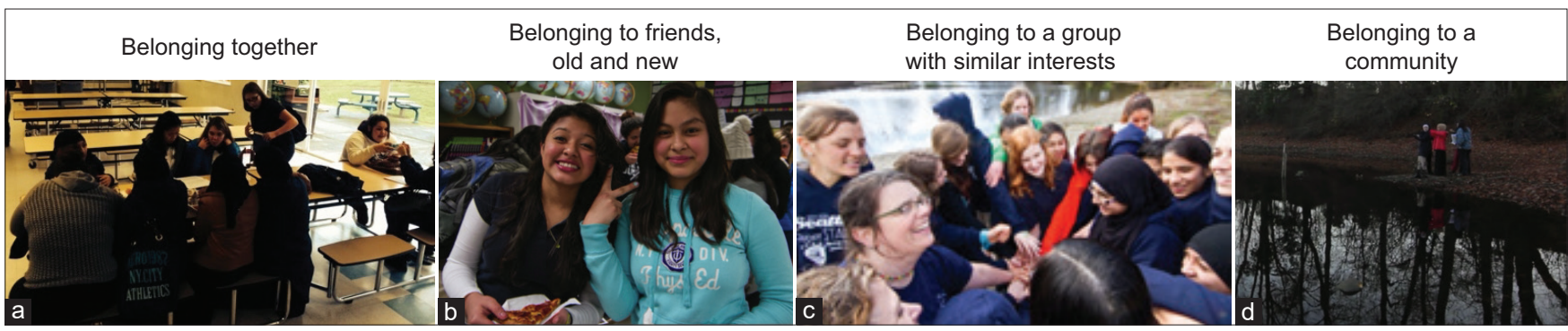

Figure 3: (a-d) Sense of belonging to each other as individuals, as whole group, and as part of larger community

her about what they did in the club, a new type of conversation that she felt proud about:

I shared with my mom. Like every time I would get out of school and she would pick me up like, "Oh, I learned this and I learned that about why the lake is so dirty," I was very excited to tell her what I learned because I want her to feel very proud of me. So I would talk with my mom and she was like, "Oh, I'm very proud of you and what did you learn?" and then she's like, "Explain this to me and like explain that."

Siskia, an eighth grader, frequently described how being in the club enabled her to talk and "actually have conversations" with her stepdad about science. He was a "science guy" and because of what she was doing in the club she was able to "talk at his level and stuff." She would follow her stepdad around their house as he worked on house projects, telling him everything about the science behind the polluted lake and what she was doing. When he asked her to wash the dishes she would shout through the house about what she did in the club, not sure if anyone was listening.

The pride in the science work was evident as parents would pick their young women up from the club and/or send letters thanking us for having the program. One mother told Emerson:

Thank you so much for making this happen. This is amazing, it's been great for her. She has fun. She gets social time in a way that we approve of and it's still academic and like it looks good on a resume, she enjoys it.

The young women decided to act in their community by producing a documentary film about their experience in the club and designing a fun and educational nature walk for the community. The nature walk consisted of four signs, each designed with a different message to help the community learn how they could help clean up Lake Evergreen: (1) Lake Evergreen in the past and present conditions, (2) information for animal lovers, (3) a comic for people of all ages, and (4) the need for installation of a bioswale, a constructed wetland. The signs and film represented a variety of ways that the young women felt that they needed to share ideas with the community. They wanted to talk across generations and even impact generations to come.
At the film showing, the theater was filled with friends, family, community scientists, neighbors, school administration and teachers, and university faculty. Before the film, the theater lobby was filled with introductions of family members, laughter, and casual talk as the community ate food and viewed the signs that were on display. The young women were excited to introduce their families to the lead teachers and have them see the film they had worked on. After the film, young women expressed how proud their families were after seeing the film.

Renee: I felt really nice because I felt like I accomplished something and my mom was proud of it. My parents were proud of it.

Tara: I feel proud of myself when my mom and dad watched that video. I feel proud when I was holding my notebook writing what we did on the...on the experience when we do the plants and things.

Anna: I was proud of it because it was like the first thing - I've never made a film before about...I don't think I've ever made a film before. So, it was cool and different. Cathy: They plugged it into the TV and they all sat to watch it and they all said that they were proud of me because I was helping the community and they said it was really cool.

Barbara: I don't know, it just made me feel proud of myself. Like I just joined a club and then I made a difference.

Vera: I felt better, like more proud, because they (her parents) actually wanted to come and see what I've been doing for the past, how long?

Brittany: I'm proud of that I get to learn more about science and then I'm actually proud of that I get to meet new people.

The feeling of pride, being proud of yourself and having others be proud of you, was another form of bonding that occurred in the group (Figure 4). It was not through the actions of one person in the group, rather it was the collective group that was proud of what they were learning and doing that made a difference in their community. As JenAnn shared after completion of the club about how working together makes an impact for the present and the future:

It sounds cheesy but amazing because this influenced all these people. So that for me was like, "Well, if in the future I want to do something similar then all I have to do is try." 


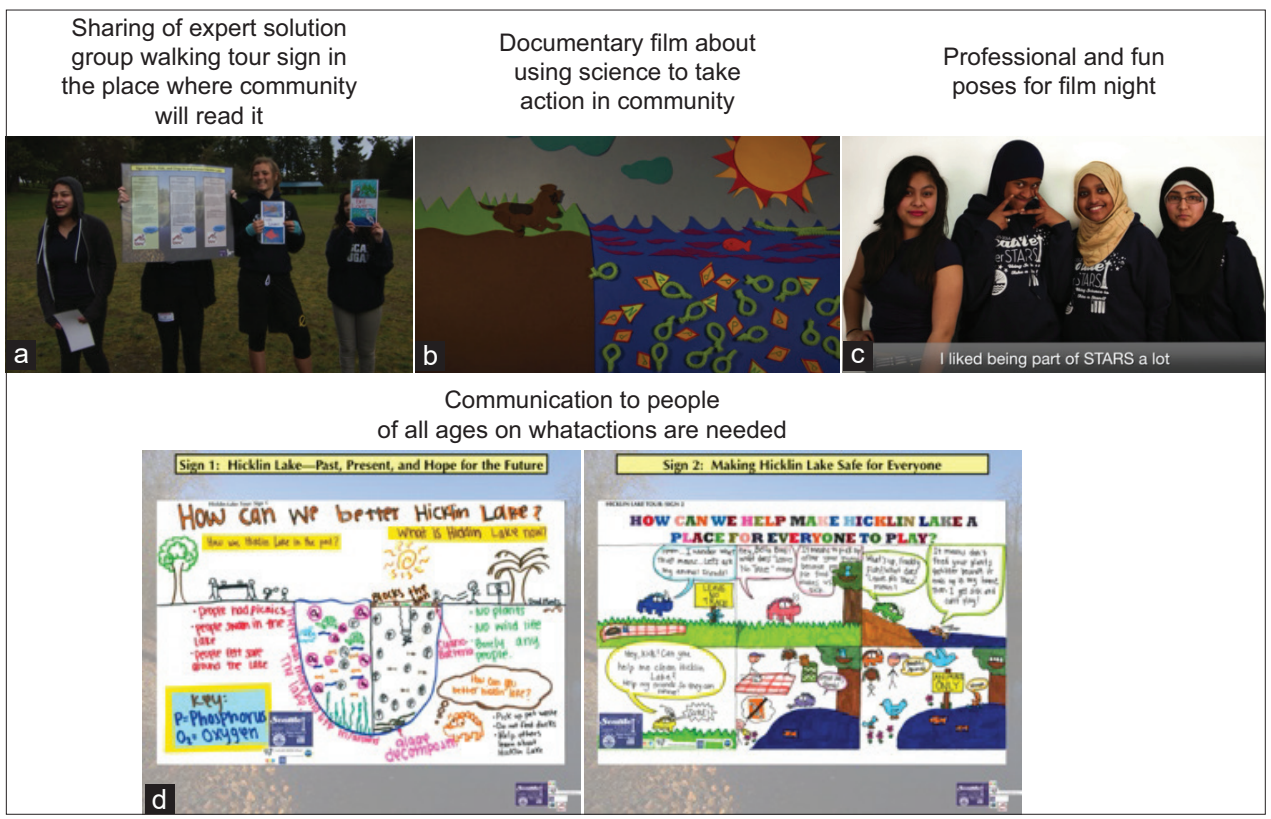

Figure 4: (a-d) Feeling proud about accomplishments

Because I've experienced something like this before... Like try for change. Try to communicate with different people, to get them to understand different things. Try to change the environment for the better. It's just you've got to try. And even if you have busy schedules if you're committed to something then you should go. Because it will make an impact on other people.

The sharing of the work that the young women did in the club was a powerful, meaningful experience for the young women. Showing the film in the district theater, having food for families and community members to share, getting on stage to talk about the work they had done in the club was a unique event that was unusual for them to experience, as expressed by JenAnn when she stated, "We don't usually get stuff like this, like in our neighborhood." Learning rigorous science and using it to be part of a living change were an empowering and pride-filled event.

\section{DISCUSSION}

In the findings section, I made four empirically based assertions based on the two research questions about how SE interactions intersect with and act as resources in science talk. I now unpack the meaning of and implications of the findings by discussing (1) the need for purposeful structures that attend to SE aspects of learning, (2) evolution of SE connected science ideas, and (3) investment of time for social and emotional interactions in science learning spaces.

\section{Purposeful Structures for Sharing Ideas}

Feeling safe and comfortable in sharing any and all ideas is a basic human right in any learning space. Intentional planning of participation structures and conversations that address the voices of students that are usually muffled or muted across learning settings will help foster the sharing of and hearing of all voices (Barton et al., 2008; Jaber and Hammer, 2016). It also enables new ideas to rise to the surface and help make progression on existing hypotheses. Holding students to a high content rigor standard along with being flexible in terms of responsiveness to ideas expressed by multiple members takes organization of allowing all voices to be heard, openness to going a different direction that planned, and a keen listener to quieter voices.

Intentional structures that foster all ideas in a learning space serve to help students make progression on ideas, furthering their participation in a community of learners. Barton et al. (2008) talked about generative science practices that enable youth to be part of a community of learners. Structures that encourage, elicit, allow for, and engage all ideas can be designed by drawing on constructs found within hybrid space theory. In hybrid spaces, youth draw on multiple resources in collective activity (Moje et al., 2004). SE interactions can be highlighted and attended to by teachers and students to connect how social interactions and the emotions we experience in learning spaces trigger learning connections.

\section{Evolving life of SE linked science ideas}

Findings reveal that when SE interactions intersect with some science ideas, they are carried together across spaces and both evolve and bloom in various activity structures across time. At first, the SE interaction acts as an engagement hook into the topic of conversation and becomes a commonly agreed upon association. For example, when Lan's group laughed at the idea of bird poop being one of the most significant causes of excess phosphates in Lake Evergreen, the science idea was connected with laughter. The birth of this connection gave rise to what can be thought of as a packaged deal that 
contains a social interaction, smiling at others, an emotional interaction, laughter, and the science idea itself. This bundle of joy, at least in this example, is nurtured as it blooms in small group and whole group conversations that eventually get taken up by others as they explain the bird poop part of a larger scientific story.

\section{Investment of time for social and emotional interactions in science learning spaces}

Albeit that establishing classroom norm is a common practice across some classrooms, more time needs to be planned to allow for relationship formation in a learning space. Akin to circle time or morning meeting in primary elementary classrooms, social relationship formation needs to be attended to across all grade levels. Norms for allowing others to feel like they can do serious work and not have to monitor extreme social behavior are necessary to respect all participants' rights to the time in the science space.

Scientists work extremely hard but also play hard too. Establishing structures in science spaces to allow for and foster having fun at the appropriate times, along with the incorporation of laughter with learning are needed. There is nothing better than a good laugh and sharing inside, sciencebased jokes while working alongside fella scientists. Planned and unplanned celebrations of individual, group, and/or community accomplishments have a feel good domino effect that trickles into other learning and everyday spaces; calling for students and adults to yearn for more interactions with each other in such spaces. Allowing students to celebrate how they are proud and how others are proud of them fosters the sense that an individual or small group of students working together can make changes that make an impact on their own and extended communities. We need students to leave learning settings feeling this way if we want to see just changes occur in society.

\section{CONCLUSION}

This study is an attempt to (re?)ignite conversations about the joy of doing and being part of productive science learning where SE interactions are supported and used as resources in science sense making. Future research is needed to consider how and where SE activity intersects with the science and engineering practices (SEP) as outlined in the NGSS (NGSS Lead States, 2013). How does SE activity intersect with SEP practices as students construct explanations of scientific phenomena? How can we as an education community attend to, allow for students to bring in who they are as their whole self with SE interactions that drive, ignite, magnetize, and draw together the love of doing science with others and telling others about it?

\section{REFERENCES}

Banks, J.A., Au, K.H., Ball, A.F., Bell, P., Gordon, E.W., Gutierrez, K.D., Brice-Heath, S., Lee, C.D., Mahiri, J., Nasir, N., Valdes, G., \& Zhou, M. (2007). Learning in and Out of School in Diverse Environments: Lifelong, Life-wide, Life-deep. Seattle, WA: The LIFE Center (University of Washington, Stanford University and SRI) and the Center for Multicultural Education, University of Washington.

Barton, A.C., \& Tan, E. (2010). We be burnin'! Agency, identity and science learning. Journal of the Learning Sciences, 19(2), 187-229.

Barton, A.C., Tan, E., \& Rivet, A. (2008). Creating hybrid spaces for engaging school science among urban middle school girls. American Educational Research Journal, 45(1), 68-103.

Davis, J.P., \& Bellocchi, A. (2018). Objectivity, subjectivity, and emotion in school science inquiry. Journal of Research in Science Teaching, 55(10), 1419-1447.

Faircloth, B.S. (2009). Making the most of adolescence: Harnessing the search for identity to understand classroom belonging. Journal of Adolescent Research, 24(3), 321-348.

Gee, J.P. (2011). An Introduction to Discourse Analysis: Theory and Method. $3^{\text {rd }}$ ed. London: Routledge.

Hamm, J.V., \& Faircloth, B.S. (2005). The role of friendship in adolescents' sense of school belonging. New Directions for Child and Adolescent Development, 107, 61-78.

Jabar, L.Z., \& Hammer, D. (2016). Engaging in science: A feeling for the discipline. Journal of the Learning Sciences, 25(2), 156-202.

Jaber, L.Z., \& Hammer, D. (2015). Learning to feel like a scientist. Science Education, 100(2), 189-220.

King, D., Ritchie, S.M., Sandhu, M., Henderson, S., \& Boland, B. (2017). Temporality of emotion: Antecedent and successive variants of frustration when learning chemistry. Science Education, 101(4), 639-672.

Moje, E.B., Ciechanowski, K.M., Kramer, K., Ellis, L., Carrillo, R., \& Collazo, T. (2004). Working toward third space in content area literacy: An examination of everyday funds of knowledge and discourse. Reading Research Quarterly, 39(1), 38-70.

NGSS Lead States. (2013). Next Generation Science Standards: For States, By States. Washington, DC: The National Academies Press.

Osterman, K.F. (2000). Students' need for belonging in the school community. Review of Educational Research, 70(3), 323-367.

Paris, D. (2012). Culturally sustaining pedagogy: A needed change in stance, terminology, and practice. Educational Researcher, 41(3), 93-97.

Paris, D., \& Winn, M.T. (2014). Humanizing Research: Decolonizing Qualitative Inquiry with Youth and Communities. Thousand Oaks, CA: Sage Publications.

Roth, W.M., Ritchie, S.M., Hudson, P., \& Mergard, V. (2011). A study of laughter in science lessons. Journal of Research in Science Teaching, 48(5), 437-458.

Sohmer, R., Michaels, S., O’Connor, M.C., \& Resnick, L. (2009). Guided construction of knowledge in the classroom: The trioka of talk, tasks, and tools. In: Schwarz, B., Dreyfus, T., \& Hershkowitz, R., (Eds.), Transformation of Knowledge through Classroom Interaction. London: Routledge. pp. 105-129.

Thomspon, J., Hagenah, S., Kang, H., Stroupe, D., Braaten, M., Colley, C., \& Windschitl, M. (2016). Rigor and responsiveness in classroom activity. Teachers College Record, 118(5), 1-58.

Warren, B., Ballenger, C., Ogonowski, M., Rosebery, A.S., \& HudicourtBarnes, J. (2001). Rethinking diversity in learning science: The logic of everyday sense-making. Journal of Research in Science Teaching, 38(5), 529-552.

Windschitl, M., Thompson, J., Braaten, M., \& Stroupe, D. (2012). Proposing a core set of instructional practices and tools for teachers of science. Science Education, 96(5), 878-903.

Yin, R.K. (2009). Case Study Research: Design and Methods. $4^{\text {th }}$ ed. Thousand Oaks, CA: Sage Publications. 